https://helda.helsinki.fi

\title{
Cliometric Approaches to War
}

\section{Eloranta, Jari Antero}

Springer International Publishing 2019

Eloranta , J A 2019 , Cliometric Approaches to War . in C Diebolt \& M Haupert (eds), Handbook of Cliometrics . 2nd ed. edn, Springer International Publishing , Cham , pp. 1299-1322 . https://doi.org/10.1007/978-3-030-00181-0_4

http://hdl.handle.net/10138/333755

https://doi.org/10.1007/978-3-030-00181-0_4

acceptedVersion

Downloaded from Helda, University of Helsinki institutional repository.

This is an electronic reprint of the original article.

This reprint may differ from the original in pagination and typographic detail.

Please cite the original version. 


\title{
Cliometric Approaches to War
}

Jari Eloranta (Appalachian State University) and Philip T. Hoffman (California Institute of Technology)

\begin{abstract}
:
This article reviews the economic history of war, a literature that comes not just from economics or from history but from political science and sociology as well. We first cover the review scholarship on the pre-modern period, especially the formation of European nation states and conflicts. It seems clear that Europeans emerged from this period with a comparative advantage in violence, through technological innovations and repeated warfare. Fiscal innovation and the expansion of state's capacity to tax were a key part of the process. The conflicts during the French Revolution and the Napoleonic period then changed the nature of warfare and ushered in an era of total war and industrialization. Then came the world wars, the period that economic historians have devoted more attention to than any other. New data and scholarship has shown the mechanics of mobilization and highlighted the importance of resources in deciding these conflicts. By contrast, the subsequent Cold War years have been relatively sparsely studied, at least from the perspective of conflicts or military spending. Given the availability of new data and the opening of many archives, it is highly likely that this state of affairs will change in the near future, and researchers may also shift to questions that arise outside of Europe and western democracies. Overall, economic historians studying war have had an impact on related long-run phenomena such as state formation, empires, and the growth of democracy. Cliometrics is well suited to the study of such topics, given the new panel and time series techniques, the rapid development of computing power, and the many new online databases.
\end{abstract}

\section{Introduction}

The theoretical and methodological impact of the cliometric approach, embodying the application of economic theories and the use of quantitative methods has been widely recognized in a number of studies on a wide number of topics. But quantitative studies of war by economic historians are somewhat rare, although in the last 20 years or so there have been many more such applications. If we take the world wars as an example, we can see how the approaches to the study of particular conflicts (or times of peace) have differed based on the scholar's theoretical and methodological leanings. Historians in general, especially diplomatic and military historians, have focused on understanding the origins of the world wars and the particular battles that took place - this has also applied to the study of other conflicts, big or small. Most of those studies have not paid adequate attention on the quantitative aspects of war; for example, Paul Kennedy's The Rise and Fall of the Great Powers. Economic Change and Military Conflict from 1500 to 2000 (1989) contains no quantitative testing of the hypothesis of hegemonic overreach and little credible numerical information to back up the findings (Eloranta 2003, Eloranta 2005).

While economic historical treatments of the costs and economic impact of wars exist, they are not abundant, and economists have not embraced the study of conflicts wholeheartedly either. For instance, the study of defense economics and military spending patterns is related to the immense expansion of military budgets and military establishments in the Cold War era. It involves the application of the methods and tools of economics to the study of government expansion in the post-Second World War era, and at least three features stand out: 1) the individuals and organizations involved (both private and public spheres of influence, for example in contracting); 2) the theoretical challenges introduced by the interaction of different institutional and organizational arrangements, both in the budgeting and the allocation procedures; 3 ) the nature of military spending, or more correctly, national defense as a public good as well as its' potential for destruction (Sandler and Hartley 1995). Most studies in the rather small field of defense economics have had a limited time span in their analyses, namely from 1945 onwards. The longer run developments and historical issues have typically fallen outside the interest of defense 
economists, although many of the tools and theoretical insights are useful for long-run analysis too.

The gap here has been filled, at least in part, by political and conflict scientists, including peace sciences. They often cover similar ground as defense economists, with a longer-run view of history, a focus on the causal factors behind the most destructive conflicts, and the determinants of state formation. One of the most significant efforts in these overlapping fields has been the Correlates of War (COW) project, which started in the spring of 1963. This project, and the researchers loosely associated with it, has had a big impact on the study of conflicts, not to mention its importance in producing comparative statistics (Singer 1979, Singer 1981, Singer 1990). Moreover, these contributions have a lot to offer to the study of long-run dynamics of military spending and warfare and the development of state fiscal capacity, a topic of interest not just in economic history, but in public economics and development economics. For example, according to Charles Tilly (1990), one of the key contributors in the study of state formation, coercion (a monopoly of violence by rulers and an ability to also wield coercion externally) and capital (the means of financing warfare, including the ability to tax and borrow) were the key elements in the European ascendancy to world domination in the early modern era. Warfare, state formation, and technological supremacy were all interrelated fundamentals of the same process.

In this chapter we review some of the applications of these interdisciplinary perspectives to the study of war, especially from the point of view of the findings that quantitative methods have brought forth. We first analyze some of the scholarship on the Middle Ages and the early modern period, especially the formation of European nation states and conflicts. We then review some of the perspectives on the French Revolution and Napoleonic wars, in particular the changed nature of conflicts and the arrival of total war, and next examine one of the most fruitful topics of study, especially from the perspective of quantitative approaches: the era of the world wars. The Cold War period is the next subject we take up. It represents a relatively unexplored frontier for economic historians of conflict, although defense economists have done more work in this area. Finally, we discuss some studies of long-run processes, especially state formation, empires, democracies, and military spending, all of which are promising areas for future work.

Much of the literature reviewed here concerns Europe, the United States, or European colonies, because that is where cliometricians have done most of their work. But there is new research on other parts of the world such as east Asia. That is second promising frontier for future cliometric scholarship, particularly on the long run relationship between warfare and state formation. 


\section{Theme 1: Medieval and Early Modern Warfare}

In Europe, the emerging nation states of the early modern period were much better equipped to fight wars than the medieval polities that had proceeded them. Frequent wars, expensive new gunpowder technologies for land and naval warfare, and the commercialization of fighting and paying for war forced these states in early modern Europe to create fiscal systems and expand their sources of revenue and ways of funding wars. Fiscal capacity of this magnitude was not unknown else in the world, but to get the needed tax revenue and to be able to borrow to finance conflicts, the western European rulers took a step that was unusual elsewhere in the world: they negotiated with elites in what would eventually become representative assemblies. Eventually the rulers had to share some of their sovereignty to be able to secure the required tax revenue and credit both domestically and abroad. The Dutch and the British were the best at this, with the latter creating an empire that spanned the globe on the eve of the First World War.

Before all this happened, most warfare in western Europe was conducted by feudal lords, who had emerged in the Middle Ages, following the collapse of the Roman Empire (or at least the Western half) and barbarian invasions. The feudal lords provided protection for communities in return for service or in kind payments. There were European kings, but even they collected little in the way of permanent taxation. Instead, they funded frequent wars out of plunder and revenue from their own personal possessions, and relied on a command system to mobilize human and material resources for large-scale military ventures (France 2001).

In this violent world, most European societies (with the exception of the Byzantine Empire) paled in comparison with the splendor and accomplishment of the empires in China and the Muslim world. But the feudal system did give Christian Western Europe one long run advantage, for in the long run it seems to have leadership stable, which eventually contributed to Europe's military resurgence (Blaydes and Chaney 2013). Furthermore, it was not until the $12^{\text {th }}$ century and the Crusades that the feudal kings engaged in larger scale operations that required supplementing revenues from personal possessions with temporary taxes to finance the conflicts, and even later that the kings began collecting substantial amounts of permanent taxation, which usually involved negotiation with elites and the first steps toward representative institutions (Blaydes and Chaney 2013, Hoffman 2015). The political ambitions of medieval kings, however, were a precursor of things to come and led to short-term fiscal deficits, which made long-term credit and prolonged military campaigns difficult. (Webber and Wildavsky 1986, Eloranta 2005)

Innovations in the waging of war and technology, especially gunpowder, arrived in Europe with a delay, which in turn permitted armies to attack and defend larger territories. This also made possible a commercialization of warfare in Europe in the $14^{\text {th }}$ and $15^{\text {th }}$ centuries as feudal armies had to give way to professional mercenary forces. The age of commercialization of warfare was accompanied by the rising importance of sea power as European states began to build their overseas empires. Portugal, the Netherlands, and England, respectively, became the "systemic leaders" due to their extensive fleets and commercial expansion in the period before the Napoleonic Wars. The early winners in the fight for world leadership, such as England, were greatly influenced by the availability of inexpensive credit, enabling them to mobilize limited resources effectively to meet military expenses.(Thomas 1983, Modelski and Thompson 1988, Ferguson 2001, Eloranta 2003). The supply of inexpensive credit required making the state a credible borrower, and doing that usually involved institutional change - in particular, sharing sovereignty with the representative institutions that had helped raised tax revenue (Cox 2016; Dincecco 2009). It was easiest to create representative institutions in urban republics and smaller 
states such as England and the Netherlands; in larger states, heterogeneous institutions and the difficulties of monitoring delegates made it hard to create national representative institution (Stasavage 2011). That was a major reason behind the success of the Netherlands and England.

These earlier efforts at expansion of armies, nation states, and credit have been studied more and more recently by economic historians and by political scientists who draw their tools from economics (Stasavage 2011, Cox 2016). While efforts such as the project and database constructed by Richard Bonney (see e.g. Bonney 1999a) ${ }^{1}$ and Philip Hoffman and Peter Lindert (see e.g. Hoffman et al. 2002) ${ }^{2}$ are illustrative of broader trends in fiscal development, they typically do not utilize econometric techniques or economic theory in the analysis explicitly. Rather, they offer data for others to use. One of the more interesting efforts that has looked at various episodes in history, including the medieval period, is the book by Brauer and van Tuyll, Castles, Battles \& Bombs. How Economics Explains Military History (2008), which argues that the events and outcomes in military history can be explained using economic theory. One of the issues they tackle is the location and layout of medieval and early modern castles. They employ the concept of opportunity costs and sunk costs to explain what were often inefficient fortifications, since castles were often expanded outward, especially after the $14^{\text {th }}$ century, as a response to the emergence of gunpowder weaponry. Moreover, they argue that diminishing marginal returns set in for bigger castles, although more remains to be studied in this respect. Such explicit use of economic theory to explain military decision-making has been rare in the literature so far, although there is a well-developed economics literature on the strategic issues involved in military spending and decisions about war and peace (Jackson and Morelli 2009, 2011; Garfinkel and Skaperdas 2007), as well as attempts to apply this literature to historical data (Hoffman 2015).

What the existing literature demonstrates is that the newly-emerging nation states in Europe began to develop more centralized and productive revenue-expenditure systems, the goal of which was to enhance the state's power and the financial resources it could mobilize for war. This also embodied a growing cost and scale of warfare. For example, during the Thirty Years' War between 100,000 and 200,000 men fought under arms, whereas twenty years later 450,000 to 500,000 men fought on both sides in the War of the Spanish Succession. The numbers notwithstanding, the Thirty Years War was a conflict directly comparable to the biggest global conflicts in terms of destruction. For instance, Charles Tilly (1990) estimated the battle deaths to have exceeded two million. Henry Kamen, in turn, emphasized the mass scale destruction and economic dislocation this caused in the German lands, especially to the civilian population (Kamen 1968, Tilly 1990). In many ways this was total war, especially considering the high numbers of civilian casualties. Cliometricians have not yet really tackled the scale and scope of this conflict adequately, using modeling and other tools frequently utilized by demographers to assess the economic dimensions of this conflict. For example, did the war have similar impacts on the demand for labor as the Black Death epidemic?

Another issue pertains to the cost of Spain's empire and whether the funding model for the state's expansion was the root cause of long-run economic decline. With the increasing scale of armed conflicts in the $17^{\text {th }}$ century, the European participants became more and more dependent on access to long-term credit, because the government that ran out of money first had to surrender. For example, even though the causes of Spain's supposed decline in the $17^{\text {th }}$ century are still disputed, nonetheless it does seem that constraints on government borrowing and the poor management of government finances caused Spanish government deficits to soar during the

\footnotetext{
${ }^{1}$ Coordinator of the European State Finance Database: http://www.esfdb.org/.

${ }^{2}$ Founders of The Global Price and Income History Group: http://gpih.ucdavis.edu/.
} 
repeated military conflicts of the $17^{\text {th }}$ century. The standard story is that as a result the Spanish Crown defaulted repeatedly during the $16^{\text {th }}$ and $17^{\text {th }}$ centuries, and on several occasions budget constraints forced Spain to halt its fighting (Kamen 2004, Kamen 2008). But is this story correct?

Douglass C. North $(1990,1993)$ has argued repeatedly that the problem was the institutional framework adopted when the Muslim kingdoms were conquered and all of Spain was placed under Christian rulers in 1492). In North's view, these institutions became a hindrance in the long run, leading Spain to lose its competitive edge vis-à-vis emerging powers like France, the Netherlands and Great Britain. However, Henry Kamen (2004) has taken a contrary point of view, emphasizing the unlike early success in Spain becoming an empire. Spain developed military expertise through empire-building, and lost its edge later than North believed; for Kamen, the root of the problem was Spanish monarchy's practice of outsourcing its expansion to foreign banks and investors. Overall, Kamen simply does not accept the thesis of long-term decline, at least as outlined by scholars like North.

It is hard to ascertain how large a role the recurring conflicts of the time period and the ensuing debt played in the decline. Cliometricians may be able to provide the most compelling arguments in this debate. In a study of late sixteenth-century Spain, Mauricio Drelichman and Hans-Joachim Voth $(2011,2014)$ show that while the king Philip II did default several times, the defaults were mere liquidity crisis, and the government was able to borrow debt fairly soon after each default. In their view, the defaults were simply outcomes that the lenders (typically foreign bankers making short term loans) and the king anticipated in loan contracts; in return for a higher interest rate, the bankers would accept later payment, if the king lacked cash because (for instance) the silver fleet was late arriving. The contracts and defaults, in short, were a way for the king to get bankers to share some of the risk. And that was not the only way Spanish monarchs borrowed. They also took out long term loans, which served as safe investments for Spanish elites (AlvarezNogal and Chamley 2014). Although these institutions may have played a role in Spain's decline, it is worth keeping in mind that they did allow the Spanish kings to fund numerous wars and expand the empire in many ways for a long time.

It is also worth recalling that the heavy taxes funding the wars fought by Spain and the other states in early modern Europe were unusual by world standards. Per-capita taxes (when measured in silver or days of unskilled labor) seem to have been much higher in western Europe than in seventeenth-century China or the Ottoman Empire, and eighteenth-century data implies that the gap widened after 1700 (Brandt et al 2014; Hoffman 2015). Although the comparisons may overlook taxes that were spent locally and omitted from central government figures in China and the Ottoman Empire, that is unlikely to eliminate the gap in per capita tax levels. Differences in per-capita income or the frequency of warfare do not explain the gap, and it likely had something to do with the agency problems facing rulers of larger states such as China and the Ottoman Empire, because tax levels are low in other big premodern states, perhaps because of agency problems facing rulers in huge states and the reliance on representative institutions in western Europe (Hoffman 2017).

\section{Theme 2: Revolutionary and Napoleonic Wars}

In the $18^{\text {th }}$ century, with rapid population growth in Europe, armies also grew in size. In Western Europe, a mounting intensity of warfare with the Seven Years War (1756-1763) finally culminated in the French Revolution and Napoleon's conquests (1792-1815). The new style of warfare brought on by the Revolutionary Wars, with conscription and war of attrition as new elements, can 
be seen in the growth of army sizes. For example, the French army grew to 650,000 men in 1793, more than 3.5 times its size in 1789. Similarly, the British army grew from 57,000 in 1783 to 255,000 men in 1816 . The Russian army was a massive 800,000 men by 1816 , a size they maintained throughout the $19^{\text {th }}$ century. However, the actual number of Great Power wars declined in absolute numbers, as did the average duration of these wars. It was the nature of war that had changed.(Eloranta 2005)

A key question for France, for example, was how to finance all these wars. According to Richard Bonney (1999b, 1999c), the cost of France's armed forces in its era of "national greatness" were stupendous, with expenditure on the army by the period 1708-1714 averaging 218 million livres, whereas during the Dutch War of 1672-1678 it had averaged only 99 million in nominal terms. This was due to both the growth in the size of the armed forces and the decline in the purchasing power of the French currency. The overall burden of war, however, remained roughly similar in this period, at least as measured by budgetary share of military expenditures (see Table 1). Furthermore, as for most European monarchies, it was the expenditure on war that (along with economic growth) brought fiscal change in France, especially after the Napoleonic wars. Between 1815 and 1913, there was a 444 per cent increase in French public expenditure and a consolidation of the fiscal system. The French government's borrowing was also centralized.

Table 1. English, French, and Prussian Defense Shares in the $17^{\text {th }}$ and $18^{\text {th }}$ Centuries

\begin{tabular}{l|l|l|l|l|l}
\hline England & \multicolumn{2}{l}{ France } & Prussia \\
\hline Year(s) & Defense Share & Year(s) & Defense Share & Year(s) & Defense Share \\
\hline 1690 & 82 & $1620-1629$ & 75 &. & - \\
1700 & 66 & $1630-1639$ & 89 &.. & - \\
1710 & 88 & $1640-1649$ & 92 &. & - \\
1720 & 68 & $1650-1659$ & 93 & $1711-1720$ & 78 \\
1730 & 63 & $1660-1669$ & 59 & $1721-1730$ & 75 \\
1741 & 77 & $1670-1679$ & 72 & $1731-1740$ & 82 \\
1752 & 62 & $1680-1689$ & 58 & $1741-1750$ & 88 \\
1760 & 88 & $1690-1699$ & 76 & $1751-1760$ & 90 \\
1770 & 64 & 1726 & 35 & $1761-1770$ & 91 \\
1780 & 89 & 1751 & 41 & $1771-1780$ & 91 \\
1790 & 63 & 1775 & 30 & $1781-1790$ & 78 \\
1800 & 85 & 1788 & 25 & $1791-1800$ & 82 \\
\hline
\end{tabular}

Sources: Calculated from the various sources in European State Finance Database (2013). See also Eloranta and Land (2011) for further details. The French figures were recalculated by Philip Hoffman.

The military spending in the late $18^{\text {th }}$ century was fairly consistent, representing the largest budgetary item for many European states (Table 1). And, whereas Prussia's defense share was continuously high, the English defense share went up and down, influenced by the various conflicts during this period. In turn, the Revolutionary and Napoleonic Wars were truly total wars based on the methods chosen by the belligerents, which affected countries outside the direct fighting. The effects of the war spilled over to influence the relations between neutrals as well. Due to the fact that these wars had an impact on the trade relations of all nations, many countries scrambled to find new outlets and sources for their trade. As a result, the bargaining power of weak (United States) and/or smaller states (Portugal - which was both weak and small), increased, albeit only temporarily.(Moreira and Eloranta 2011)

Scholars have paid too little attention to the smaller players in times of war, often assuming that they occupied an insignificant role in conflicts. Moreira and Eloranta (2011) have argued, this is an erroneous assumption, especially in the context of major conflicts. For instance, the United 
States was a weak state as well, and for the most part remained neutral during this period due to its short existence and limited military power. Nonetheless, US played an important role in world trade before it became a hegemon after the Second World War. Still, it is natural to focus most of the analysis on the great empires such as Great Britain and France. After all, it is staggering to conceptualize the evolution of an empire like Great Britain, from its humble beginnings in the $16^{\text {th }}$ century, to the building of the navy and its first major victory against the Spanish Armada, to the multicultural, industrialized empire that ruled the world in the $19^{\text {th }}$ century. Perhaps it was the intense nature of these rivalries and the total wars between the great powers that explains why the great powers had to rely on alliances (often with lesser powers) to complement their war efforts and retain access to crucial strategic resources. Therefore, even a great power like Great Britain had to tolerate the activities of the neutral states, sometimes to the detriment of their own war efforts.

In recent years many scholars have analyzed the disruptions caused by major conflicts like the world wars. Reuven Glick and Alan Taylor (2010) studied the indirect economic effects of wars, in particular the First and the Second World War, with a large database, using an econometric gravity model. Their analysis, focusing on disruptions of trade and the subsequent economic losses, yielded clear results: trade was disrupted by such massive wars, and did not return to prewar levels. Furthermore, these economic disruptions affected even those countries that were not directly involved in the conflict. These findings may be applicable to other large-scale conflicts as well, even in the pre-industrial era.

Furthermore, many scholars have doubted the efficacy of economic warfare, which can range from fairly benign policy measures and pressure to outright warfare in the context of total war (O'Leary 1985, Førland 1993, Naylor 2001). Lance Davis and Stanley Engerman (2006) have studied one particular form of economic warfare, naval blockades, spanning several centuries. They also emphasize both the costs and challenges of sustaining a successful blockade. For example, during the Napoleonic wars, the legalities of blockades was unclear, especially the issue of neutrality. The success of a blockade, as they point out, is often difficult to assess as well.(Crouzet 1964) Periods of actual warfare, even blockades, can bring substantial opportunities, as well as disruptions, for trade. As other scholars have argued, rising relative prices and substantial profits may be the answer to why such risky situations bring forth increases in trade (Thornton and Ekelund 2004). Moreover, recent scholarship, as represented by David Bell (2007), for example, certainly puts the revolutionary wars and the ensuing Napoleonic conflicts into the same category as the world wars. Finally, Kevin O'Rourke (2006) has provided cliometric insights into the Revolutionary and Napoleonic wars by focusing on the contraction of trade in particular. His results show that Great Britain was the least affected of the belligerents, whereas France and the United States suffered more. The welfare losses were around 5-6 per cent of GDP for the United States, which could be classified as substantial.

\section{Theme 3: World Wars}

The last four decades leading to the First World War were a period of an intensifying arms race. As argued by Eloranta (2007), the military burdens incurred by the Great Powers also varied in terms of timing, suggesting different reactions to external and internal pressures. Nonetheless, the aggregate, systemic real military spending of the period showed a clear upward trend for the entire period. Moreover, the impact of the Russo-Japanese War was immense for the total (real) spending of the sixteen states examined in Eloranta (2007), since they were both Great Powers and Russian 
military expenditures alone were massive. The unexpected defeat of the Russians, along with the arrival of dreadnoughts, launched an even more intensive arms race (Hobson 1993). The basic parameters of the military spending by the most important participants are listed in Table 2 .

Table 2. Military Burdens (=Military Spending as a Percentage of GDP) and Defense Shares (=Military Spending as a Percentage of Central Government Expenditures) of Sixteen Countries, 1870-1913

\begin{tabular}{|c|c|c|c|c|c|c|}
\hline $\begin{array}{l}\text { COUNTRY (or } \\
\text { Group) }\end{array}$ & $\begin{array}{l}\text { Mean } \\
\text { Military Burden }\end{array}$ & $\begin{array}{l}\text { Military Burdens, } \\
\text { Standard } \\
\text { Deviation }\end{array}$ & $\begin{array}{l}\text { Mean } \\
\text { Shares }\end{array}$ & Defense & $\begin{array}{l}\text { Defense } \\
\text { Standard } \\
\text { Deviation }\end{array}$ & Shares. \\
\hline$A U T^{*}$ & 3.47 & 0.98 & 12.03 & & 3.69 & \\
\hline$B E L$ & 1.88 & 0.48 & 14.54 & & 3.67 & \\
\hline$D E N$ & 1.89 & 0.50 & 29.93 & & 7.47 & \\
\hline$F R A^{*}$ & 3.68 & 0.55 & 25.91 & & 3.69 & \\
\hline$G E R^{*}$ & 2.56 & 0.42 & 54.12 & & 13.45 & \\
\hline$I T A^{*}$ & 2.75 & 0.68 & 21.69 & & 5.22 & \\
\hline$J A P^{*}$ & 4.99 & 4.63 & 32.24 & & 17.59 & \\
\hline$N E D$ & 2.77 & 0.32 & 26.18 & & 2.65 & \\
\hline NOR & 5.54 & 1.37 & 85.33 & & 29.48 & \\
\hline POR & 1.34 & 0.14 & 18.95 & & 2.32 & \\
\hline$R U S^{*}$ & 3.87 & 1.63 & 27.91 & & 5.56 & \\
\hline$S P A$ & 2.01 & 0.64 & 21.35 & & 6.22 & \\
\hline$S W E$ & 2.13 & 0.21 & 35.93 & & 3.99 & \\
\hline$S W I$ & 1.12 & 0.32 & 60.21 & & 5.66 & \\
\hline$U K^{*}$ & 2.63 & 0.97 & 37.52 & & 7.89 & \\
\hline$U S A^{*}$ & 0.74 & 0.25 & 29.43 & & 10.50 & \\
\hline Great Powers $(=*)$ & 3.09 & 1.26 & 30.11 & & 8.45 & \\
\hline $\begin{array}{l}\text { Small and Medium } \\
\text { Powers (=the rest) }\end{array}$ & 2.33 & 0.50 & 36.55 & & 7.68 & \\
\hline
\end{tabular}

Sources: see Eloranta (2007) for details.

In August of 1914, this military capacity was unleashed in Europe with horrible consequences, sparking the First World War, which lasted more than four years. Another total war had begun, now taking place in the industrial era. About nine million combatants and twelve million civilians died during the so-called Great War, with property damage concentrated in France, Belgium, and Poland. There have been many new studies that have analyzed the war, in particular The Economics of World War I, edited by Stephen Broadberry and Mark Harrison (2005a). What do we know about the economic damages caused by the war? According to Rondo Cameron and Larry Neal (2003), the direct financial losses arising from the Great War were circa 180-230 billion 1914 U.S. dollars, whereas the indirect losses of property and capital rose to over 150 billion dollars. According to Broadberry and Harrison (2005b), the economic losses arising from the war could be as high as 692 billion 1938 U.S. dollars. But how much of their resources did they have to mobilize and what were the human costs of the war?

The early phase of the First World War involved mobilizing the troops and the immediate economy for warfare. For Germany, the most viable strategy was one which could bring a victory quickly in the situation of geopolitical encirclement by the hostile powers (Ferguson 1999). The possibility that the conflict would be prolonged and that Germany and its ally Austria-Hungary would have to fight a war of attrition on two fronts was not taken into serious consideration (Stevenson 2011, Strachan 2011). Great Britain serves as an example of state-directed industrial mobilization. The primary forms of state involvement were co-optation and coordination, not 
command and compulsion. By bringing in new manufacturers to war production, building new public factories, and buying munitions abroad, the government inadvertently promoted decentralization of the industry and sponsored competition among manufacturers. In a similar fashion, the market-based mechanism of transactions with raw materials had not disappeared; the governmental control in this sphere was accepted as a forced and a temporary measure. During the first two years of the war, the government essentially refrained from intervening in food matters. Unlike all major continental countries, Britain never established a full monopoly on grain. The rationing of some other foods was introduced only five months before the end of war. To sum up, the British industry operated as a capitalist market economy, not an administered economy.(Blum and Eloranta 2013)

Many of the features of a market economy fully applied to the wartime French economy. More than any other economic system, the French economy was an example of self-mobilization and self-organization of production. Although industrial mobilization was sponsored by the government, industrialists themselves came to play a primary role in organizing mass production of arms and munitions. French resource-allocation institutions, the consortia, represented a weak and temporary version of corporate organization. For about three years during the war the French authorities limited themselves to very few measures of food regulation. What little regulation they imposed was mostly in the form of price controls on some foods. Because of large imports of food from overseas, more dramatic measures of food control did not seem necessary. The government only introduced a grain monopoly and the rationing of bread late in 1917.(Blum and Eloranta 2013)

Allied great powers were also able to mobilize their resources more effectively during the war. Even though the Central Powers initially did quite well with the limited resources they had, the Allies were able to mobilize their far superior economic and military resources better both at the home front and on the front lines. Their more democratic institutions supported the demands of the total war effort better than their authoritarian counterparts, especially in terms of being able to mobilize their societies farther than their competitors. Therefore, the richer countries mobilized more men and materiel for the war, and their war industries proved quite capable of adapting to fulfill the needs of the war machine.(Broadberry and Harrison 2005b)

Moreover, having a large peasant population turned out to be a hindrance for the production of food under wartime constraints. In poorer countries, and even in affluent Germany, mobilization efforts siphoned off resources from agriculture and the farmers preferred to hoard food rather than sell it for low prices. As Avner Offer (1989) has argued, food (or the lack thereof) played a crucial part in Germany's collapse. Germany's problem was not so much that it was not able to mobilize resources for the war, but the fact that its main ally, Austria-Hungary, was a poor nation with limited resources and plagued by an inability to mobilize effectively. The collective mobilization of resources by the Allies proved too big an obstacle for Germany to overcome.(Blum 2011, Blum 2013, Blum and Eloranta 2013)

Ultimately, resources and mobilization were weaknesses of the Central Powers, and led to their defeat, after the overextension of their supply lines in the spring of 1918. After the ceasefire in 1918 and the Versailles peace treaty of 1919, Germany experienced political instability and economic turmoil. A complex process of interactions between a military defeat, an exhausted economy, the burden of reparations and war debt, and an uncertain political future laid the basis for three more turbulent decades. One consequence of the war and the war economy, which is believed to have contributed to the destruction of the Weimar Republic, was the hyperinflation experienced between 1921 and 1923. By 1923, the average price indices for food prices and retailer prices (with $1913=1$ ) were 198 billion and 166 billion, respectively, while wages rose 
disproportionally. Wage indices $(1913=1$ for them as well) for skilled workers in 1923 were 85 billion, while corresponding figures for unskilled and civil servants were 100 and 56, respectively(Blum 2013, Blum and Eloranta 2013). Even though hyperinflation served as a stimulus, especially for the exporting sectors, and helped delete considerable amounts of internal and non-reparation foreign debt, the inflation's aggregate effect was disastrous: German GDP dropped by one third from 1922 to 1923.

Moreover, Albrecht Ritschl (2005) has argued that conditions for peace were simultaneously too lax and too strict, and the way Germany, especially the German public, perceived the end of this conflict was not realistic. He maintains that Germany's military was technically defeated, but Germany had not yet been invaded by Allied troops. German leaders had not been captured and the capital had not been besieged or conquered; in fact, German territory remained by and large unscathed and the Emperor managed to escape to the neutral Netherlands. Soon legends spread, saying that the lack of morale at the home front was sabotaging military strength - the birth of the stab-in-the-back legend. It was difficult to realize the inevitable defeat in the absence of obvious evidence; it took another coalition of Allied forces to complete this task in 1945. Illusions about the 'true' reason for the lost war and financial disasters helped right-wing propagandists stir-up hatred against ethnic and political minorities.

On the macroeconomic consequences, Feinstein et al. (1997) have identified four direct economic outcomes that arose from the conflict: 1) Two immediate exogenous shocks, in terms of disruptions of supply and demand as well as excess mobilized production (and military) capacity after the conflict; 2) A more rigid economic environment, due in part to diminished wage flexibility; 3) A weaker financial structure, since the economies had to carry the new, increased levels of public spending as well as the acquired debts with mainly pre-war levels of taxation; 4) A fragile international monetary system. The "winners" of the war, at least in terms of economic growth effects, seemed to be the neutral states, such as the Nordic countries, who outperformed other Western states.

Ronald Findlay and Kevin O'Rourke (2007) have summarized the challenges brought on by the period of world wars in their aftermath for global trade and politics. First of all, there were three wartime adjustments that had serious consequences in the interwar period: 1) non-European producers increased their role during the war, and the subsequent price competition; 2) industrial expansion during wartime, which was difficult to redirect after the conflict; 3 ) the boost in nonEuropean industrialization. In terms of broader effects, they list: 1) the increased importance of turbulent domestic politics; 2) the legacy of the war debts; 3) the difficulties in returning to the Gold Standard; 4) the creation of new nation states; 5) the Communist revolution and state in Russia; 6) the creation of instability and conditions as a result of the First World War that would lead to the Second World War.

There have been many studies of the interwar period, especially the disarmament and rearmament processes that took place. For example, studies on German rearmament have typically focused on the war period. However, Max Hantke and Mark Spoerer (2010) have studied the hidden military spending of the 1920s, utilizing classic cliometric techniques such as counterfactual analysis. Their basic aim is to analyze the economic importance of the Versailles Treaty, i.e. reparations, on the German economy. To do so, they devised a clever strategy. Their counterfactual framework was to estimate what the impact of "normal," unrestricted military spending would have been on the German economy if there had been no Treaty restrictions on their armed forces. In doing so they conclude that the size of that spending, as well as its impact, would have been roughly equal, and that the failure of the Weimar economy was due to domestic 
policies. At the heart of this failure were fiscal effects and constraints imposed by the loss of territory and industrial capacity. In their analysis, Hantke and Spoerer showed considerable ingenuity in reconstructing the German budgetary figures for the turbulent 1920s. Their discussion of reparations and their impact is also reminiscent of Eugene White's (2001) work on the FrancoPrussian war of 1870-71 and its aftermath.

For the interwar period, one could also ask why the League of Nations ultimately failed to achieve widespread disarmament, its most fundamental goal. Eloranta (2011) has shown that the League of Nations' failure could be traced back to two faults: the lack of adequate security guarantees for its members (like a credible alliance, for example the NATO); and missing the disarmament goals it set out in the 1920s and 1930s. The League, in short, was doomed from the outset to fail, because of built-in institutional contradictions. In terms of economic theory and econometric analysis, the League of Nations can also be modeled and analyzed as a military alliance. Based on Eloranta's (2011) analysis, the results are fairly conclusive: The League of Nations did not function as a pure public-good alliance, which encouraged an arms race in the 1930s.

In the interwar period many countries maintained fairly high military spending levels, despite tendencies to disarm, particularly in the 1920s. The mid-1930s marked the beginning of intense rearmament whereas some of the authoritarian regimes had begun earlier in the decade. Germany, under Hitler, increased its military burden from 1.6 per cent in 1933 to 18.9 per cent in 1938, a rearmament program combining creative financing and promising both guns and butter for the Germans. Mussolini was not quite as successful in his efforts to realize the new Roman Empire, with a military burden fluctuating between four and five per cent in the 1930s (5.0 per cent in 1938). The Japanese rearmament drive was perhaps the most impressive, with a military burden as high as 22.7 per cent and greater than 50 per cent defense share in 1938. For many countries, such as France and Russia, the rapid pace of technological change in the 1930s rendered many of the earlier armaments obsolete only two or three years later (Eloranta 2002).

Mark Thomas (1983) has analyzed the British rearmament using an adjusted version of input-output tables for the 1930s, which enabled him to examine the causal interdependencies in the economy. He argued that the rearmament helped alleviate the effects of the recession, essentially making a Keynesian argument about the government's fiscal policy. Crafts and Mills (2013) have challenged this recently, making a case for a lower multiplier effect, in the range of 0.3 to 0.8 . They also discuss at length the previous models of estimating the impact, and note that the theoretical findings are, by and large, model-dependent. Their choice is to use the more recent time series techniques, which take into account potential problems of endogeneity. This debate is far from resolved, like the debate over broader 1930s spending programs like the New Deal. ${ }^{3}$

In the Second World War, the initial phase from 1939 to early 1942 favored the Axis as far as strategic and economic potential was concerned. After that, the war of attrition, with the United States and the USSR joining the Allies, turned the tide in favor of the Allies. For example, in 1943 the Allied total GDP was 2,223 billion international dollars (in 1990 prices), whereas the Axis accounted for only 895 billion. Also, the impact of the Second World War was much more profound for the economies of the participants. For example, Great Britain at the height of the First World War incurred a military burden of circa 27 per cent, whereas the military burden level consistently held throughout the Second World War was over 50 per cent.(Harrison 1998, Eloranta 2003)

\footnotetext{
${ }^{3}$ See Fishback and Kachanovskaya (2010) as an example of this debate.
} 
Other Great Powers experienced similar levels of spending. Only the massive economic resources of the United States made possible its lower military burden. The UK and the United States also mobilized their central / federal government expenditures efficiently for the military effort. In this sense the Soviet Union fared the worst, and additionally the share of military personnel out of the population was relatively small compared to the other Great Powers. On the other hand, the economic and demographic resources that the Soviet Union possessed ultimately ensured its survival during the German onslaught. On the aggregate, the largest personnel losses were incurred by Germany and the Soviet Union. They were many times those of the other Great Powers. In comparison with the First World War, the second one was even more destructive and lethal, and the aggregate economic losses from the war exceeded 4,000 billion 1938 U.S. dollars. After the war, the European industrial and agricultural production amounted to only half of the 1938 total.(Harrison 1996, Harrison 1998, Harrison 2000)

The Second World War has been extensively covered in recent economic history scholarship. The Economics of World War II, edited by Mark Harrison, is a good collection of such efforts. For example, although Britain and Germany had significantly different buildups to war, the war itself brought extreme economic activity where both nations had virtually zero unemployment and economies geared towards the production of armaments. From 1933-1944, Germany's GDP and GDP per capita rose every year. Naturally, the end of the war brought economic collapse to Germany, with a serious drop off in both 1945 and 1946 (33 and 50 percent respectively). Similarly, the UK experienced significant growth in its GDP and GDP per capita during the first years of the war. By 1943, however, the UK's economic growth began to slow down, and GDP actually dropped in both 1944 and 1945 GDP, though the decline was not as devastating as in Germany (Broadberry and Howlett 1998, Abelshauser 2000).

In Germany's total munitions output increased monthly for every year of the war, until September 1944, when production finally began to wane. However, German productivity in machine tools decreased throughout the rest of the war, falling to 79 percent of 1939 levels. Even the production of coal suffered a drop in productivity, falling to 75 tons per shift per worker from the 1939 peak of 100 tons. Some of this productivity loss was due to labor shortages or disputes.

In the UK, although coal production fell, the agricultural sector experienced a seemingly miraculous increase in efficiency. Despite the departure of experienced workers for the armed services and a drop in food imports of 70 percent or more, agricultural production was able to increase the calories per employee by nearly 77 percent from 1937 levels. Women, volunteer labor, and eventually prisoners of war all filled in for the agricultural workers in the armed forces. In parts of the economy, production varied wildly from industry to industry. (Broadberry and Howlett 1998, Abelshauser 2000).

Finally, the war had immediate and long term impacts on the economic development of these economies. In Germany, rationing began even before the war began, with the cost of living increasingly steadily for the average family, particularly for food. By 1944, food prices had increased to 113 percent of 1938 prices, and clothing had risen to 141 percent of 1938 prices. As a result of these higher prices and rationing, the average caloric intake for a worker's family member fell from 2,435 calories in 1939-40 to 1,412 by 1945-46.(Abelshouser 2000) Of course, the dismantling of the German state and economy following the war left little doubt of the destructive power that the Second World War had on the economies of Europe. Even victors, such as the UK, experienced heavy losses. If measured by physical capital, the British lost 18.6 percent of its prewar wealth.(Broadberry and Howlett 1998) This left many concerned that the state 
planned to continue nationalizing industries (though that fear never materialized). In the end, every nation in Europe felt the economic pain of war.

\section{Theme 4: Cold War and Beyond}

The end of the Second World War brought with it a new global order, with the USA and the Soviet Union as the most dominant players in global security affairs. With the establishment of NATO in 1949, a formidable defense alliance was formed by the Western countries. The USSR, rising to new prominence due to the war, in turn established the Warsaw Pact in 1955. The war also meant a change in the public spending and taxation levels of most Western nations. Military spending levels followed increases in welfare and social spending, and peaked during the early Cold War. The American military burden increased above 10 per cent in 1952-1954, and stayed at a high level thereafter, with the post-war burden up to 1991 averaging 6.7 per cent (up until 1991). Great Britain and France followed the American example after the Korean War.(Eloranta 2003)

The Cold War was tied to an extensive arms race, with nuclear weapons as the main investment item, with the USSR spending circa 60 to 70 per cent of the American level in the 1950s, and the USSR briefly spending more than the United States in the 1970s (see Figure 1). Nonetheless, the United States maintained a massive advantage over the Soviets in terms of nuclear warheads. Yet, the comparative spending figures suggest that NATO had a 2-to-1 lead in spending vis-à-vis the Warsaw Pact in the 1970s and early 1980s. Some of this armaments race was due to technological advances that led to increases in the cost per soldier - it has been estimated that technological increases have produced a mean annual increase in real costs of circa 5.5 per cent in the post-war period. However, the "bang for the buck" increased drastically with the introduction of nuclear weapons and other new weapons systems.(Ferguson 2001, Eloranta 2005)

Figure 1. Military Burdens (=MILBUR) of the United States and the United Kingdom, and the Soviet Military Spending as a Percentage of the US Military Spending (ME), 1816-1993 

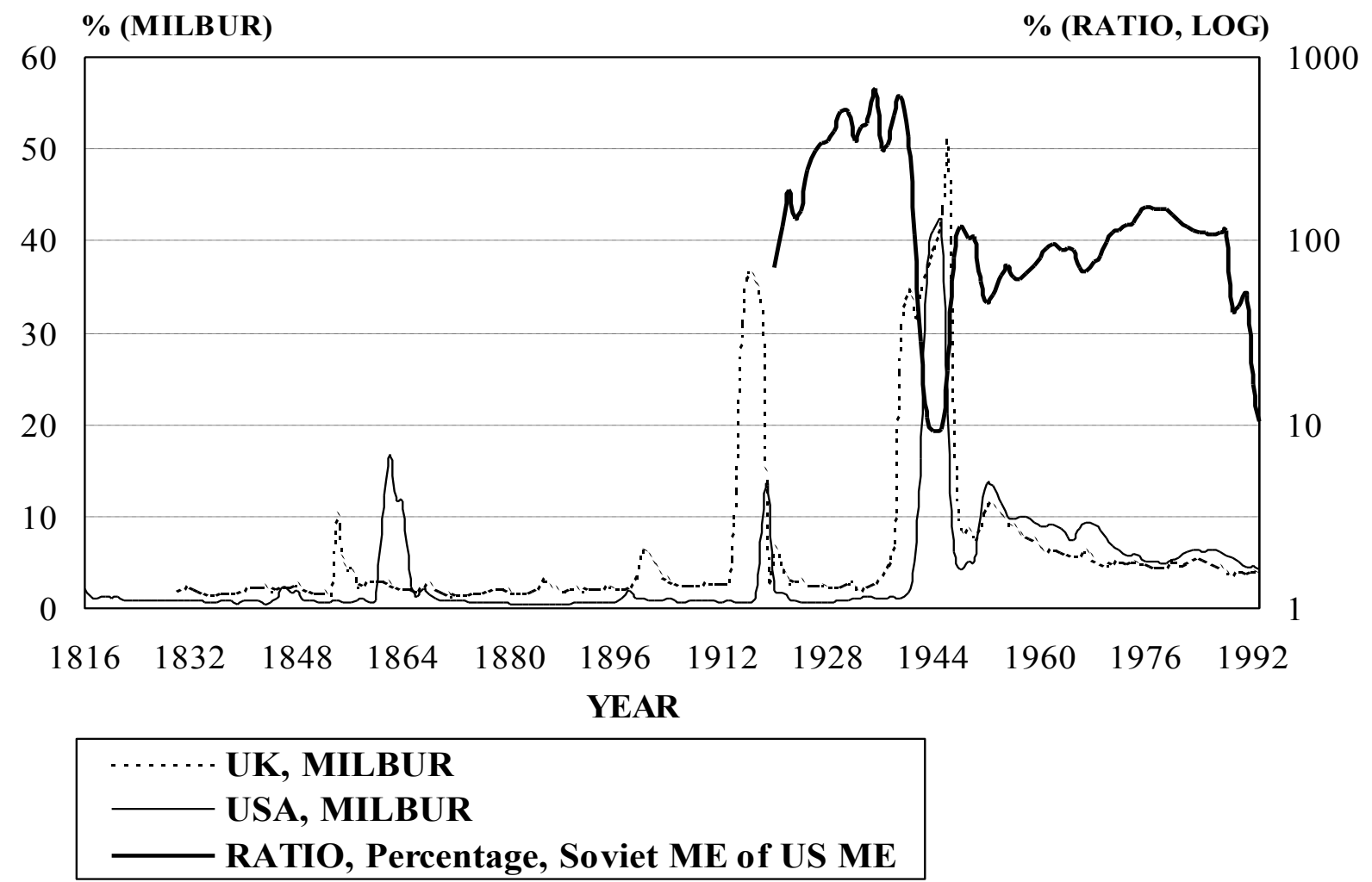

Sources: see Eloranta (2005) for details on the sources and methods of calculation.

While the Second World War has been studied at length, the Cold War conflicts and military spending have not. However, some themes have been explored, for example the so-called Military Industrial Complex (MIC), which refers to the influence that the military and industry had on each other's policies. If the negative connotations are emphasized, it refers to the unduly large influence that military producers might have over the public sector's acquisitions, and foreign policy in particular, in what amounts to a collusive relationship. In fact, the origins of this type of interaction can be found further back in history. As Paul Koistinen (1980) has emphasized, the First World War was a watershed in business-government relationships, since businessmen were often brought into government to make supply decisions during this total conflict. Most governments, as a matter of fact, needed the expertise of the core business elites during the world wars. In the United States some form of MIC came into existence before 1940. Similar developments can be seen in other countries before the Second World War, for example in the Soviet Union. The Cold War simply reinforced these tendencies (Koistinen 1980, Harrison 2003, Eloranta 2009). Findings by example Robert Higgs (Trevino and Higgs 1992, Higgs 1994) establish that the financial performance of the leading defense contracting companies was, on the average, much better than that of comparable large corporations during the period 1948-1989. Nonetheless, his findings do not support the normative conclusion that the profits of defense contractors were abnormal.

The Cold War arms race has been ignored by economic historians; most of the studies have been conducted by defense economists. Beginning with Mancur Olson and Richard Zeckhauser's path-breaking work on NATO (Olson and Zeckhauser 1966), there have been many testable hypotheses relating to the idea of collective security provision in an alliance and the implications of this provision on military spending. As Olson's and Zeckhauser's logic implies, pure public good alliances are characterized by free riding by the smaller (or poorer) states, since they have a 
reasonable expectation of military assistance from the larger nations under a cohesive defensive arrangement. For example, recent studies have found that the pure public good alliance concept describes NATO until about 1966, when a change in the strategic doctrine forced the members to rely more on their own military provision (Sandler and Hartley 1999).

The argument here, which rests on the theory of public goods, has sound theoretical foundations. Indeed, Olson and Zeckhauser (1966) found a significant positive correlation between the NATO allies' GNP and their military burdens in 1964, indicating clear free-riding behavior by the smaller allies. Later studies specified the pure public good alliance to describe NATO until 1966, when the positive rank correlation between the variables ceased to be statistically significant (Sandler and Murdoch 1990, Sandler and Hartley 1999).

Another interesting field of debate is how the Cold War ended. It is obviously a topic that is fraught with political importance as well as scholarly debate. The list of possible explanatory factors is long indeed (see e.g. Kegley Jr 1994). Moreover, there is a big debate over the collapse of the Soviet Union. Economic historians have delved into this question too. For example, Mark Harrison (2002) has analyzed the issue by developing a simple model of costs and benefits for a dictator and producer of the command system. His conclusion is that a command system was not necessarily inherently unstable; rather the stability was conditional, based on the equilibrium surrounding the level and application of coercion. In the case of the Soviet Union, the lessening of the threat of coercion that came with perestroika policies unraveled the system. Harrison used historical statistical and archival data on military spending to prove his assertions.

Nonetheless, despite these analyses, economic historians have not yet been very active in the debate over the scale and scope of the Cold War and the impacts of the arms race. Economic historians have been more interested in the so-called Golden Age of Economic Growth (19501973), the evolution of the European Union, and the Marshall Plan (Maddison 1989, Berger and Ritschl 1995, Eichengreen 1995, Maddison 2001, Ritschl 2004). Most of this domain has been occupied by defense economists and political scientists. The opening of various archives and new data sources will certainly change this state of affairs in the near future.

\section{Theme 5: Long-run Analyses: Military spending, societal structures, and empires}

Economic historians have typically been more interested than economists in general in the longrun development of societies. Political and conflict scientists, as well as sociologists, have been drawn to the same issues and even the same time periods, but not always from the same angle or using the same methods. However, even though some cycle theorists and conflict scientists have been interested in the formation of modern nation states and the respective system of states since 1648, they have not expressed any real interest in pre-modern societies and warfare (Wright 1942, Blainey 1973, Levy 1985, Geller and Singer 1998, Levy 1998). Economic historians have continuously extended their reach back to earlier periods, especially since new data is now available to analyze, for example, state formation.

Political scientists have also investigated patterns in how states develop. For George Modelski and William R. Thompson (1988, 1996), and for proponents of Kondratieff waves and long cycles as explanatory forces in the development of world leadership patterns, states rise to prominence through naval power. One neglected topic in most studies of competition between the states is the effect of military expenditure on both military and economic leadership. It is often argued, for example, that uneven economic growth causes nations to compete for economic and military prowess. The leader nation has to dedicate increasing resources to armaments in order to maintain its position, while the other states, the so-called followers, can benefit from greater 
investments in other areas of economic activity. The follower states thus act as free-riders in the international system stabilized by the hegemon leader. A built-in assumption in this hypothesized development pattern is that military spending eventually becomes harmful for economic development; a notion that has often been challenged based on empirical studies (Kennedy 1989, Eloranta 2005).

There have been relatively few credible attempts to model the military (or budgetary) spending behavior of states based on their long-run regime characteristics. Here we will elaborate on three in particular: Webber-Wildawsky (1986) model of budgeting; Richard Bonney (1999a) model of fiscal systems; and Niall Ferguson (2001) model of interaction between public debts and forms of government. Caroly Webber and Aaron Wildawsky maintain that each political culture generates its characteristic budgetary objectives; namely, productivity in market regimes, redistribution in sects (specific groups dissenting from an established authority), and more complex procedures in hierarchical regimes. Their model, however, is essentially a static one. It does not provide clues as to why the behavior of nations may change over time, especially over long time periods.

Richard Bonney (1999a) has addressed this problem in his writings on the early modern states. He has emphasized that the states' revenue and tax collection systems, the backbone of any militarily successful nation state, have evolved over time. For example, in most European states the government became the arbiter of disputes and the defender of certain basic rights in the society by the early modern period. During the Middle Ages, the European fiscal systems were relatively backward and autarchic, with mostly predatory rulers (or roving bandits, as Mancur Olson (1993) has coined them). In his model this would be the stage of the so-called tribute state. Next in the evolution came, respectively, the domain state (with stationary bandits, providing some public goods), the tax state (more reliance on credit and revenue collection), and finally the fiscal state (embodying more complex fiscal and political structures). A superpower like Great Britain in the $19^{\text {th }}$ century had to be a fiscal state to be able to dominate the world, due to all the burdens that went with an empire (Ferguson 2003).

One serious problem with Bonney scheme is that is peculiar to Europe and does not generalize to the rest of the world, or even to Europe in the era of the Roman Empire (Hoffman 2017). Progress here will require economic models that capture the problems facing political leaders in premodern states, be they kings and emperors, or the leaders of ancient republics and democracies. How should such a leader design a fiscal system, given demands to fund wars and the risk of internal struggles for power? Even an autocrat can enhance his power by making concessions that win support among elites (Myerson 2008)

For the modern period, Niall Ferguson (Ferguson 2001, Ferguson 2006) has furnished an interesting account of how nations have prepared to finance wars and survive the fighting. For him, wars have shaped all the most relevant institutions of modern economic life: tax-collecting bureaucracies, central banks, bond markets, and stock exchanges. Moreover, he argues that the invention of public debt instruments has gone hand-in-hand with more democratic forms of government and military supremacy - hence, the so-called Dutch or British model. These regimes have also been the most efficient economically, which has in turned reinforced the success of this fiscal regime model. In his view, military expenditures may have been the principal cause of fiscal innovation for most of history. Ferguson's model highlights the importance, for a state's survival among its challengers, of the right institutions, appropriate technology, and a healthy dose of ambition. But his model, and none of the others either, utilize extensive quantitative testing or 
methods in order to test their claims, which will make this field of inquiry a fruitful one in the future.

Cliometricians have already brought a lot to the table as well, especially concerning the long-run development of states, regime type, and financial/fiscal evolution. For example, Philip Hoffman (Hoffman and Rosenthal 1997, Hoffman 2011) has shown that it is possible to analyze the military sector and technology over several centuries, in fact before the industrial revolutions. He discovered, mostly based on analysis of price data, that Western Europe developed a comparative advantage in violence long before 1800. European military industries exhibited tremendous productivity growth in the early modern period, which gave them the edge, particularly in gunpowder technologies. Hoffman (2012) has also introduced an interesting (and testable) model to explain where this comparative advantage came from, namely the tournament model. In this model winning wars and technological development to gain the edge with a country's competitors were intricately intertwined. And this led to giving the Europeans an edge in their military development, and contributed to the building of empires.

Economic historians have also engaged heavily in the debate over the expansion, functioning, and profitability of empires, for example the British empire. Such critiques, of course, go back centuries, to such pivotal figures as Adam Smith (1776) or John Hobson (1965 reprint), who were very skeptical about the profitability of the British Empire and who ultimately benefited from the empire. More recently, several scholars, including Avner Offer (1993), Patrick O'Brien (1988), Lance Davis and Robert Huttenback $(1982,1986)$, and Niall Ferguson $(2003,2004)$ have weighed in on this question. The various tools of economic historians have been employed to tackle these questions. Davis and Huttenback maintained, on the basis of econometric exercises and modeling, that the profits from the empire were not sufficient to contribute to the overall economic growth of Britain, and that the middle class incurred a larger share of the relative costs than the elites. In a related fashion, O'Brien argued, also along the lines of Smith and Hobson, that the empire was an unnecessary expenditure that dragged Britain to a multitude of conflicts, at high cost, and that the costs were borne unequally, mainly by mainland Britons. Offer, by contrast, has criticized some of these findings, raising questions about the data underlying the claims and about the role that military expenditures have played in the building of the empire. He in turn uses alliance theories to explain the unequal allocation of expenditures within the empire. In a different fashion, Ferguson has also attempted to highlight some of the benefits of the empire, for example the ability to trade within a large area.

Another set of issues to which cliometricians have contributed heavily is the formation of states in the long run. Along with the scholars that we have already discussed, Mark Dincecco (2009, 2010, Dincecco and Prado 2012) has made some significant contributions to the debate over the fiscal revolution of European states. Typically employing newer panel data and related techniques, he found that: centralization and limitations on political power led to higher revenues among European states; pre-modern war casualties were correlated with fiscal institutions, and that improvements in fiscal capacity possibly led to higher economic returns; and that Eastern and Western Europe, measured by the river Rhine, diverged institutionally after 1789. Moreover, in a similar fashion, David Stasavage et al., prominent political scientists, have discovered that between 1600 and 2000 the biggest factors in the rise and fall of the mass army were changes in transportation and communications technology, and that mobilization for the needs of total warfare in the $20^{\text {th }}$ century led to the emergence of substantial redistribution of wealth and progressive taxation (Onorato et al. 2012, Scheve and Stasavage 2010). Outside of Europe, Sng and coauthors 
have attempted to model the very different long run development of fiscal capacity in East Asia (Sng 2014; Sng and Moriguchi 2014; Ko, Koyama, and Moriguch 2018).

In turn, Mark Harrison and Nikolaus Wolf (2011) have examined a different aspect of the development of states, namely the development of democracies and warfare. The topic of so-called democratic peace, implying that democracies do not fight one another, is vast and very interdisciplinary (see e.g. Russett 1993, De Mesquita, Morrow et al. 1999, Choi 2011, Gowa 2011, Dafoe and Russett 2013). Harrison and Wolf (2014) argue that this widely accepted thesis may not always hold, especially when analyzing the development of states from 1870 onwards. They claim that trade and democracy do not always work to prevent conflicts, but can in fact lead to increasing the capacity for war and the frequency of conflicts. This entry has inspired some debate over the very legitimacy of the concept of the democratic peace (Gleditsch and Pickering 2014, Harrison and Wolf 2014).

\section{Conclusion}

There is wide variety of work on war in history, political sciences, sociology, and economics. This article reviews how economic historians have applied this research to the study of war, and it pays particular attention to how economic history has enriched the debate over the causes, buildup, costs, and outcomes of conflicts. We would argue that economic historians, using a variety of techniques ranging from simple data tools to more complicated econometric exercises, have often broadened the scope of the scholarly debates, enabling both more comprehensive long-run analysis of conflicts and political development as well as deeper understanding of particular wars and historical periods.

This review began by examining the scholarship on medieval and the early modern periods, especially the formation of states in Europe and the role that warfare played in their political development. We returned to these themes toward the end of the review as well, when we looked at long-run processes both in Europe and the rest of the world as well. In sum, it seems clear that Europeans emerged out of this period with a comparative advantage in violence, which they achieved through technological innovations, repeated warfare, and heavy military spending. Fiscal innovation and expansion was a key part of the process. We then moved to a pivotal era in history, the wars of the French Revolution and the Napoleonic Empire. This period represented a change in the nature of warfare, the arrival of total war tactics and strategies in earnest, the emergence of new kinds of states, and the advent of the industrial age. The $19^{\text {th }}$ century represented a period of globalization and relatively few conflicts, but it also set the stage for the destructive $20^{\text {th }}$ century.

The period of the world wars is perhaps the area of study that has attracted the greatest attention from economic historians, at least in recent years. Many scholars have now delved into the economic dimensions and impacts of the conflicts, as well as the disarmament/rearmament of the interwar period. New data and scholarship has shown the mechanics of mobilization and highlighted the importance of resources in deciding these conflicts. By contrast, the Cold War period has been little, at least from the perspective of conflicts or military spending. Given the availability of new data and the opening of many archives, it is highly likely that this state of affairs will change in the near future. The same holds for work on long-run phenomena such as state formation, empires, and democracy, where much needs to be done, particularly for parts of the world outside of Europe. These topics demand comparative study, which is ideally suited for cliometrics, especially given the new panel and time series econometric techniques that are 
available, the rapid development of computing power, and the creation of many new online databases.

\section{References:}

Abelshauser, W. (2000). Germany: guns, butter, and economic miracles. The economics of World War II. Six great powers in international comparison. M. Harrison. Cambridge, Cambridge University Press: 122-176.

Álvarez-Nogal, C., and C. Chamley (2014). "Debt Policy under Constraints: Philip II, the Cortes, and Genoese Bankers.” Economic History Review 67(1): 192-213.

Bell, D. (2007). The First Total War: Napoleon's Europe and the Birth of Warfare as We Know It. New York, Houghton Mifflin Harcourt.

Berger, H. and A. Ritschl (1995). "Germany and the Political Economy of the Marshall Plan, 194752: A Re-Revisionist View." Europe's Postwar Recovery: 199-245.

Blainey, G. (1973). The causes of war. New York: Free Press.

Blaydes, L. and E. Chaney (2013). "The Feudal Revolution and Europe's Rise: Political Divergence of the Christian West and the Muslim World before 1500 CE." American Political Science Review 107(01): 16-34.

Blum, M. (2011). "Government decisions before and during the First World War and the living standards in Germany during a drastic natural experiment." Explorations in Economic History 48(4): 556-567.

Blum, M. (2013). "War, food rationing, and socioeconomic inequality in Germany during the First World War." The Economic History Review 66(4): 1063-1083.

Blum, M. and J. Eloranta (2013). War Zones, Economic Challenges, and Well-being Perspectives on Germany during the First World War. War: Global Assessment, Public Attitudes and Psychological Effect. N. Miller, Nova Publishers.

Bonney, R., Ed. (1999a). The Rise of the Fiscal State in Europe c. 1200-1815. Oxford, Oxford University Press.

Bonney, R. (1999b). Introduction. The Rise of the Fiscal State in Europe c. 1200-1815. R. Bonney. Oxford, Oxford University Press: 1-17.

Bonney, R. (1999c). France, 1494-1815. The Rise of the Fiscal State in Europe c. 1200-1815. R. Bonney. Oxford, Oxford University Press.

Brandt, L., D. Ma, et al. (2014). "From Divergence to Convergence: Re-evaluating the History Behind China's Economic Boom.” Journal of Economic Literature 52(1): 45-123.

Brauer, J. and H. v. Tuyll (2008). Castles, Battles \& Bombs. How Economics Explains Military History. Chicago, Chicago University Press.

Broadberry, S. and M. Harrison, Eds. (2005a). The Economics of World War I. Cambridge, UK, Cambridge University Press.

Broadberry, S. and M. Harrison (2005b). The Economics of World War I: An Overview. The Economics of World War I. S. Broadberry and M. Harrison. Cambridge, UK, The Cambridge University Press.

Broadberry, S. and P. Howlett (1998). The United Kingdom: 'Victory at all costs'. The economics of World War II. Six great powers in international comparisons. M. Harrison. Cambridge, UK, Cambridge University Press.

Cameron, R. and L. Neal (2003). A Concise Economic History of the World. From Paleolithic Times to the Present. Oxford, Oxford University Press. 
Choi, S. W. (2011). "Re-Evaluating Capitalist and Democratic Peace Models1." International Studies Quarterly 55(3): 759-769.

Cox, Gary W. (2016). Marketing Sovereign Promises: Monopoly Brokerage and the Growth of the English State. Cambridge, Cambridge University Press.

Crafts, N. and T. C. Mills (2013). "Rearmament to the Rescue? New Estimates of the Impact of "Keynesian" Policies in 1930s' Britain." The Journal of Economic History 73(04): 10771104.

Crouzet, F. (1964). "Wars, blockade, and economic change in Europe, 1792-1815." Journal of Economic History: 567-588.

Dafoe, A. and B. Russett (2013). "Does capitalism account for the democratic peace? The evidence still says no." Assessing the Capitalist Peace: 110-126.

Davis, L. E. and R. A. Huttenback (1982). "The political economy of British imperialism: measures of benefits and support." The Journal of Economic History 42(01): 119-130.

Davis, L. E. and R. A. Huttenback (1986). Mammon and the pursuit of Empire: The political economy of British Imperialism, 1860-1912. Cambridge, Cambridge University Press.

Davis, L. E. and S. L. Engerman (2006). Naval blockades in peace and war: an economic history since 1750. Cambridge; New York, Cambridge University Press.

De Mesquita, B. B., J. D. Morrow, R. M. Siverson and A. Smith (1999). "An institutional explanation of the democratic peace." American Political Science Review: 791-807.

Dincecco, M. (2009). "Fiscal centralization, limited government, and public revenues in Europe, 1650-1913." The Journal of Economic History 69(01): 48-103.

Dincecco, M. (2010). "Fragmented authority from Ancien Régime to modernity: a quantitative analysis." Journal of Institutional Economics 6(3): 305.

Dincecco, M. and M. Prado (2012). "Warfare, fiscal capacity, and performance." Journal of Economic Growth 17(3): 171-203.

Drelichman, M. and H. J. Voth (2011). "Lending to the Borrower from Hell: Debt and Default in the Age of Philip II*." The Economic Journal 121(557): 1205-1227.

Drelichman, M. and H.-J. Voth (2014). Lending to the Borrower from Hell: Debt, Taxes, and Default in the Age of Philip II, Princeton, Princeton University Press.

Eichengreen, B. (1995). Europe's Postwar Recovery, Cambridge, Cambridge University Press.

Eloranta, J. (2002). External Security by Domestic Choices: Military Spending as an Impure Public Good Among Eleven European States, 1920-1938 Dissertation, European University Institute.

Eloranta, J. (2003). National Defense. The Oxford Encyclopedia of Economic History. J. Mokyr. Oxford, The Oxford University Press: 30-33.

Eloranta, J. (2005). "Military Spending Patterns in History." EH.Net Encyclopedia. URL: http://eh.net/encyclopedia/article/eloranta.military.

Eloranta, J. (2007). "From the great illusion to the Great War: Military spending behaviour of the Great Powers, 1870-1913." European Review of Economic History 11(2): 255-283.

Eloranta, J. (2009). "Rent seeking and collusion in the military allocation decisions of Finland, Sweden, and Great Britain, 1920-381." The Economic History Review 62(1): 23-44.

Eloranta, J. (2011). "Why did the League of Nations fail?" Cliometrica 5(1): 27-52.

Eloranta, J. and J. Land (2011). "HOLLOW VICTORY? BRITAIN'S PUBLIC DEBT AND THE SEVEN YEARS' WAR." Essays in Economic \& Business History 29.

European State Finance Database (2013). Online database, managed by Richard Bonney. Accessed March 1, 2013. URL: http://www.esfdb.org/Default.aspx. 
Feinstein, C. H., P. Temin and G. Toniolo (1997). The European economy between the wars. Oxford ; New York, Oxford University Press.

Ferguson, N. (1999). The Pity of War. Explaining World War I. New York, Basic Books.

Ferguson, N. (2001). The cash nexus: money and power in the modern world, 1700-2000. New York, Basic Books.

Ferguson, N. (2003). Empire: the rise and demise of the British world order and the lessons for global power. New York, Basic Books.

Ferguson, N. (2004). Colossus: the price of America's empire. New York, Penguin Press.

Ferguson, N. (2006). The war of the world: twentieth-century conflict and the descent of the West. London, Allen Lane.

Findlay, R. and K. O'Rourke (2007). Power and Plenty: Trade, War, and the World Economy in the Second Millennium. Princeton, Princeton University Press.

Fishback, P. V. and V. Kachanovskaya (2010). In search of the multiplier for federal spending in the states during the new deal, National Bureau of Economic Research.

Førland, T. E. (1993). "The history of economic warfare: international law, effectiveness, strategies." Journal of Peace Research: 151-162.

France, J. (2001). "Recent Writing on Medieval Warfare: From the Fall of Rome to c. 1300." The Journal of Military History 65(2): 441-473.

Garfinkel, M. R., and S. Skaperdas (2007). "Economics of Conflict: An Overview.” Handbook of Defense Economics. Ed. T. Sandler and K. Hartley. Amsterdam, Elsevier, vol. 2: 649-709.

Geller, D. S. and J. D. Singer (1998). Nations at war: a scientific study of international conflict. Cambridge; New York, NY, Cambridge University Press.

Gleditsch, K. S. and S. Pickering (2014). "Wars are becoming less frequent: a response to Harrison and Wolf." The Economic History Review 67(1): 214-230.

Glick, R. and A. M. Taylor (2010). "Collateral damage: Trade disruption and the economic impact of war." The Review of Economics and Statistics 92(1): 102-127.

Gowa, J. (2011). "The democratic peace after the cold war." Economics \& Politics 23(2): 153-171.

Hantke, M. and M. Spoerer (2010). "The imposed gift of Versailles: the fiscal effects of restricting the size of Germany's armed forces, 1924-9." The Economic History Review 63(4): 849864.

Harrison, M. (1996). Accounting for war: Soviet production, employment, and the defence burden, 1940-1945. Cambridge, Cambridge University Press.

Harrison, M. (1998). The economics of World War II: an overview. The economics of World War II. Six great powers in international comparisons. M. Harrison. Cambridge, UK, Cambridge University Press.

Harrison, M. (2000). The Soviet Union: the defeated victor. The economics of World War II. Six great powers in international comparison. M. Harrison. Cambridge, Cambridge University Press: 268-301.

Harrison, M. (2002). "Coercion, compliance, and the collapse of the Soviet command economy." The Economic History Review 55(3): 397-433.

Harrison, M. (2003). "Soviet Industry and the Red Army Under Stalin: A Military-Industrial Complex?" Les Cahiers du Monde russe 44(2-3): 323-342.

Harrison, M. and N. Wolf (2014). "The frequency of wars: reply to Gleditsch and Pickering." The Economic History Review 67(1): 231-239.

Higgs, R. (1994). "The Cold War Economy. Opportunity Costs, Ideology, and the Politics of Crisis." Explorations in Economic History 31(3): 283-312. 
Hobson, J. A. (1965 (reprint)). Imperialism. Ann Arbor, University of Michigan Press.

Hobson, J. M. (1993). "The Military-Extraction Gap and the Wary Titan: The Fiscal Sociology of British Defence Policy 1870-1914." Journal of European Economic History 22(3): 466507.

Hoffman, P. and J.-L. Rosenthal (1997). "The political economy of warfare and taxation in early modern Europe: historical lessons for economic development." The Frontiers of the New Institutional Economics: 31-55.

Hoffman, P. T., D. S. Jacks, P. A. Levin and P. H. Lindert (2002). "Real inequality in Europe since 1500." The Journal of Economic History 62(02): 322-355.

Hoffman, P. T. (2011). "Prices, the military revolution, and western Europe's comparative advantage in violence." The Economic History Review 64(s1): 39-59.

Hoffman, P. T. (2012). "Why Was It Europeans Who Conquered the World?" The Journal of Economic History 72(03): 601-633.

Hoffman, P. T. (2015). Why Did Europe Conquer the World? Princeton: Princeton University Press.

Hoffman, P. T. (2017). "Public Economics and History: A Review of Fiscal Regimes and the Political Economy of Premodern States, Edited by Andrew Monson and Walter Scheidel." Journal of Economic Literature, 55(4), 1556-69.

Jackson, M. O., and M. Morelli (2009). "Strategic Militarization, Deterrence, and Wars.” Quarterly Journal of Political Science 4: 279-313. (2011). The Reasons for Wars-An Updated Survey. Handbook on the Political Economy of War. Ed. C. Coyne and R. Mathers. New York, Elgar.Kamen, H. (1968). "The Economic and Social Consequences of the Thirty Years' War." Past and Present April: 44-61.

Kamen, H. (2004). Empire: How Spain Became a World Power, 1492-1763, HarperCollins, New York.

Kamen, H. (2008). Imagining Spain: historical myth \& national identity, Yale University Press, New Haven, CT and London.

Kegley Jr, C. W. (1994). "How Did the Cold War Die? Principles for an Autopsy." Mershon International Studies Review: 11-41.

Kennedy, P. (1989). The Rise and Fall of the Great Powers. Economic Change and Military Conflict from 1500 to 2000. London, Fontana.Ko, C. Y., Koyama, M., \& Sng, T. H. (forthcoming 2018). "Unified china and divided europe." International Economic Review.

Koistinen, P. A. C. (1980). The Military-Industrial Complex. A Historical Perspective. Foreword by Congressman Les Aspin. New York, Praeger Publishers.

Levy, J. S. (1985). "Theories of General War." World Politics 37(3): 344-374.

Levy, J. S. (1998). "The Causes of War and the Conditions of Peace." Annual Review of Political Science 1(1): 139.

Maddison, A. (1989). The world economy in the 20th century. Paris, OECD Publications and Information Center distributor.

Maddison, A. (2001). The World Economy: A Millennial Perspective. Paris, OECD.

Myerson, R. B. (2008). "The autocrat's credibility problem and foundations of the constitutional state.” American Political Science Review, 102(1), 125-139.

Modelski, G. and W. R. Thompson (1988). Seapower in global politics, 1494-1993. Houndmills, Basingstoke, Hampshire, Macmillan Press. 
Modelski, G. and W. R. Thompson (1996). Leading Sectors and World Powers. The Coevolution of Global Politics and Economics. Columbia, South Carolina, University of South Carolina Press.

Moreira, C. and J. Eloranta (2011). "Importance of «weak» states during conflicts: Portuguese trade with the United States during the Revolutionary and Napoleonic wars." Revista de Historia Económica 29(03): 393-423.

Morrow, J. D. (1993). "Arms versus allies: trade-offs in the search for security." International Organization 42(2): 207-233.

Naylor, R. T. (2001). Economic Warfare: Sanctions, Embargo Busting, and Their Human Cost. Boston, Northeastern University Press.

North, D. C. (1990). Institutions, institutional change, and economic performance. Cambridge; N.Y., Cambridge University Press.

North, D. C. (1993). "Institutions and credible commitment." Journal of institutional and Theoretical Economics 149: 11-11.

O'Brien, P. K. (1988). "The Costs and Benefits of British Imperialism, 1846-1914." Past and Present(120): 163-200.

Offer, A. (1989). The First World War: An Agrarian Interpretation. Oxford, Clarendon Press.

Offer, A. (1993). "The British Empire, 1870-1914: A Waste of Money?" The Economic History Review 46(2): 215-238.

Olson, M. and R. Zeckhauser (1966). "An Economic Theory of Alliances." Review of Economics and Statistics 48(3): 266-279.

Olson, M. (1993). "Dictatorship, Democracy, and Development." American Political Science Review 87(3): 567-576.

O'Leary, J. P. (1985). "Economic warfare and strategic economics." Comparative Strategy 5(2): 179-206.

Onorato, M. G., K. Scheve and D. Stasavage (2012). Technology and the Era of the Mass Army. IMT Lucca EIC Working Papers Series. Lucca, IMT Lucca. 5.

O'Rourke, K. (2006). "The worldwide economic impact of the French Revolutionary and Napoleonic Wars, 1793-1815." Journal of Global History 1(1): 123-149.

Ramey, V. A. (2011). "Can government purchases stimulate the economy?" Journal of Economic Literature 49(3): 673-685.

Ritschl, A. (2004). "The Marshall Plan, 1948-1951." EH. Net Encyclopedia: http://eh.net/encyclopedia/the-marshall-plan-1948-1951/.

Ritschl, A. (2005). The pity of peace: Germany's economy at war, 1914-1918 and beyond. The Economics of World War I. S. Broadberry and M. Harrison. Cambridge, Cambridge University Press: 41.

Russett, B. (1993). Grasping the Democratic Peace. Principles for a Post-Cold War World. Princeton, New Jersey, Princeton University Press.

Sandler, T. and K. Hartley (1995). The economics of defense. Cambridge, Cambridge University Press.

Sandler, T. and K. Hartley (1999). The Political Economy of NATO. Past, Present, and into the 21st Century. New York, Cambridge University Press.

Sandler, T. and J. C. Murdoch (1990). "Nash-Cournot or Lindahl Behavior?: An Empirical Test for the Nato Allies." Quarterly Journal of Economics 105(4): 875-894.

Scheve, K. and D. Stasavage (2010). "The conscription of wealth: mass warfare and the demand for progressive taxation." International Organization 64(4): 529-562. 
Singer, J. D. (1979). The Correlates of War I: Research Origins and Rationale. New York, Free Press.

Singer, J. D. (1981). "Accounting for International War: The State of the Discipline." Journal of Peace Research 18(1, Special Issue on Causes of War): 1-18.

Singer, J. D. (1990). Variables, Indicators, and Data. The Measurement Problem in Macropolitical Research. Measuring the Correlates of War. J. D. Singer and P. Diehl. Ann Arbor, University of Michigan Press.

Smith, A. (1776). An Inquiry into the Nature and Causes of the Wealth of Nations, ed. London, Edwin Canna.

Sng, T. H. (2014). "Size and dynastic decline: The principal-agent problem in late imperial China, 1700-1850." Explorations in Economic History, 54: 107-127.

Sng, T. H., \& Moriguchi, C. (2014). "Asia's little divergence: State capacity in China and Japan before 1850." Journal of Economic Growth, 19(4), 439-470.

Stasavage, D. (2011). States of credit: Size, power, and the development of European polities. Princeton: Princeton University Press.

Stevenson, D. (2011). "From Balkan Conflict to Global Conflict: The Spread of the First World War, 1914-1918." Foreign Policy Analysis 7: 169-182.

Strachan, H. (2011). "Clausewitz and the First World War." The Journal of Military History 75(April): 367-391.

Thomas, M. (1983). "Rearmament and Economic Recovery in the late 1930S*." The Economic History Review 36(4): 552-579.

Thornton, M. and R. B. Ekelund (2004). Tariffs, Blockades, and Inflation: The Economics of the Civil War, Rowman \& Littlefield.

Tilly, C. (1990). Coercion, Capital, and European States, AD 990-1990. Cambridge, Mass, Basil Blackwell.

Trevino, R. and R. Higgs (1992). "Profits of US defense contractors." Defence and Peace Economics 3(3): 211-218.

Webber, C. and A. Wildavsky (1986). A History of Taxation and Expenditure in the Western World. New York, Simon and Schuster.

White, E. N. (2001). "Making the French pay: The costs and consequences of the Napoleonic reparations." European Review of Economic History 5(3): 337-365.

Wright, Q. (1942). A study of war. Chicago, Ill.,, The University of Chicago Press. 